Supporting Information

\title{
Nitrogen-Doped Carbon Cages Encapsulating CuZn Alloy for Enhanced $\mathrm{CO}_{2}$ Reduction
}

\author{
Xiaosong $\mathrm{Hu},{ }^{\dagger}$ Chaoyue Zhao,${ }^{\dagger}$ Xin $\mathrm{Hu},{ }^{\dagger}$ Qingxin Guan, ${ }^{*}, \dagger$ Yanlin Wang ${ }^{\dagger}$ and Wei \\ $\mathrm{Li}^{*, \dagger, \dagger}$ \\ ${ }^{\dagger}$ College of Chemistry, State Key Laboratory of Elemento-Organic Chemistry, Key Laboratory of \\ Advanced Energy Materials Chemistry (Ministry of Education), Nankai University, Tianjin 300071, \\ China \\ ${ }^{\ddagger}$ Collaborative Innovation Center of Chemical Science and Engineering (Tianjin), Nankai University, \\ Tianjin 300071, China \\ E-mail: qingxinguan@nankai.edu.cn \\ E-mail:weili@nankai.edu.cn
}




\section{Contents}

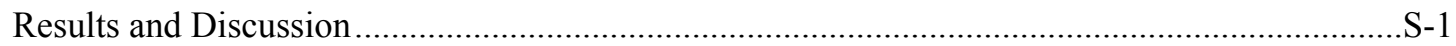

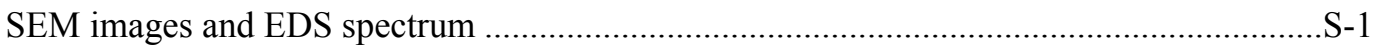

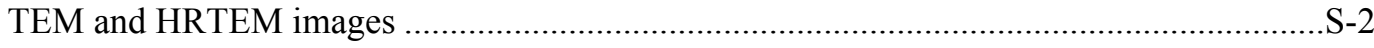

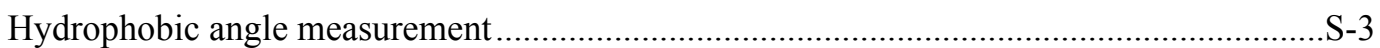

XRD patterns and TGA result of the Cu-doped ZIF-8 precursor...........................................S-3

XRD patterns of the CuZn@C-N samples ............................................................................

EXAFS and XANES spectra of the CuZn@C-N sample ......................................................... -5

XPS spectra of Cu@ZIF-8 and CuZn@C-N ............................................................................. -6

FT-IR spectra of the CuZn@C-N samples ..............................................................................

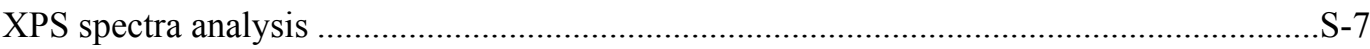

Element content analysis in shell of CuZn@C-N.................................................................

Physical properties of different samples ........................................................................

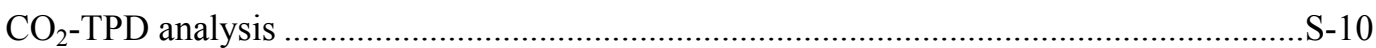

Element content analysis of metal in CuZn@ $\mathrm{C}-\mathrm{N}$ samples .................................................. -10

Adsorption models of $\mathrm{CO}_{2}$ by DFT calculations....................................................................

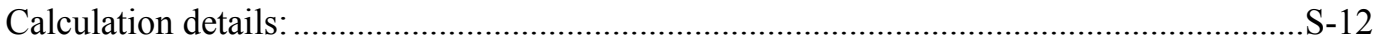

XRD patterns of the $\mathrm{CuO}-\mathrm{ZnO}$ precursor with different treatment .......................................

Comparison of the RWGS catalytic performances .......................................................... -12

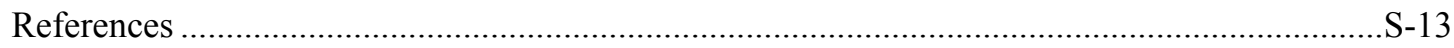




\section{Results and Discussion}

\section{SEM images and EDS spectrum}
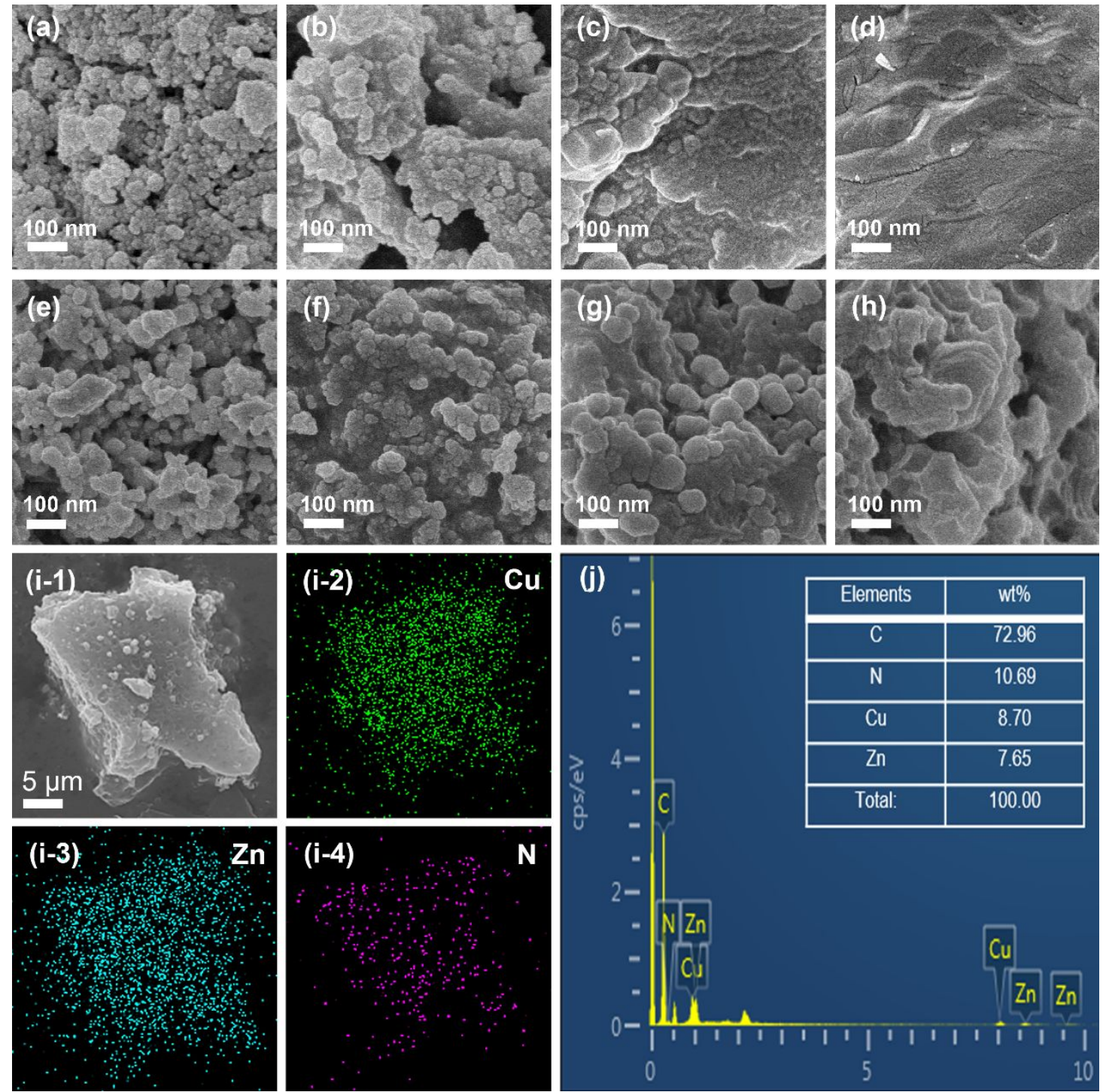

Figure S1. SEM images of the Cu-doped ZIF-8 precursor including the different molar ratio between the ligand and $\mathrm{ZnO}$ a) $0.5: 1$, b) $1: 1$, c) $3: 1$, d) $5: 1$ and the different etching time e) $3 \mathrm{~h}, \mathrm{f}) 6 \mathrm{~h}, \mathrm{~g}) 12 \mathrm{~h}, \mathrm{~h}) 18 \mathrm{~h}$. It is worth noting that the etching time is $18 \mathrm{~h}$ when the molar ratio is investigated, and the molar ratio is fixed to 5:1 when the etching time is modulated. i) Mapping and j) EDS of the different elements of the Cu@ZIF-8 sample $(5: 1,18 \mathrm{~h})$. 


\section{TEM and HRTEM images}

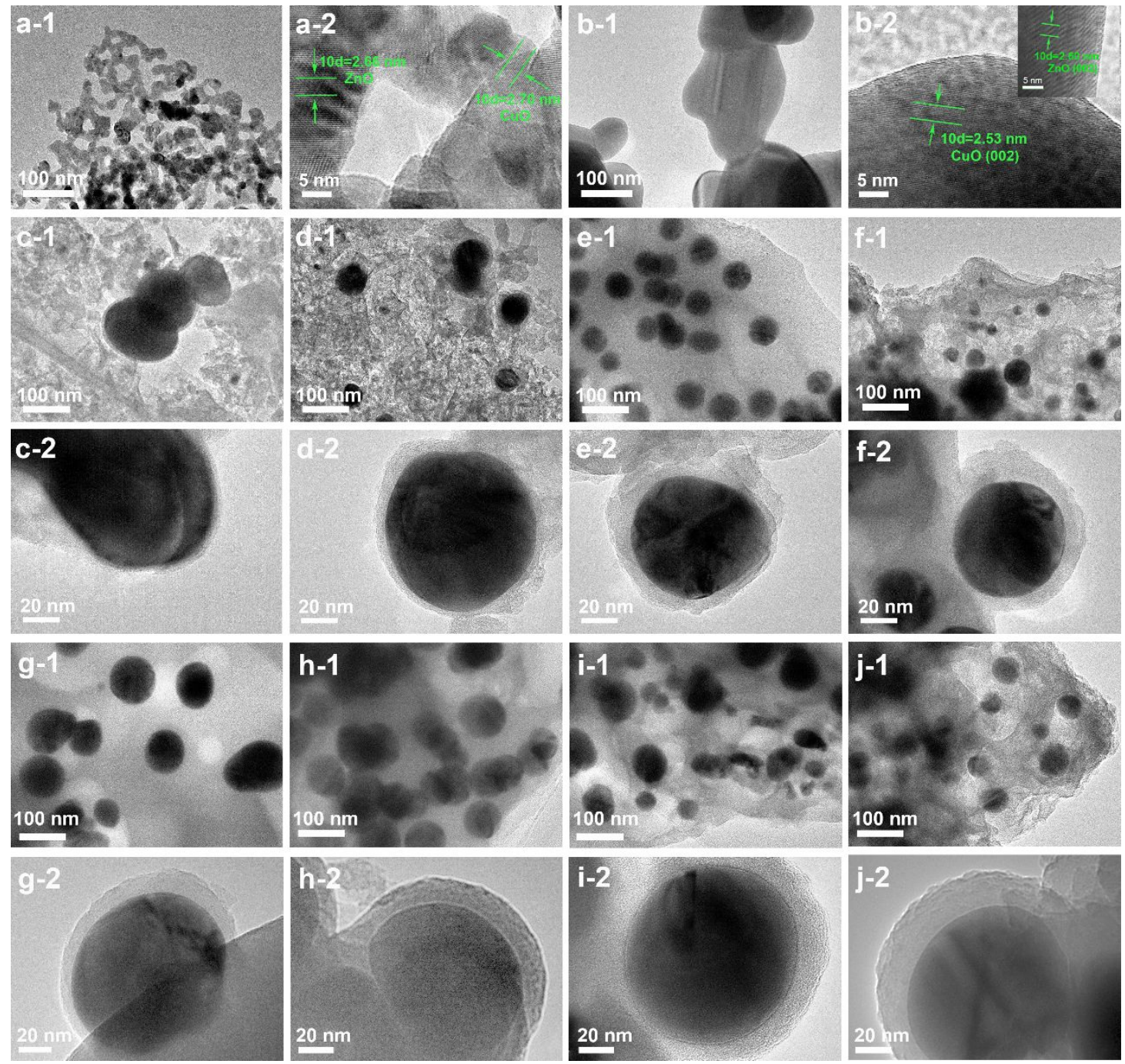

Figure S2. TEM and HRTEM images of $\mathrm{CuO}-\mathrm{ZnO}$ a) calcined at $400{ }^{\circ} \mathrm{C}$ and b) calcined at $500{ }^{\circ} \mathrm{C}$. TEM images of the $\mathrm{CuZn} @ \mathrm{C}-\mathrm{N}$ including the different molar ratio between the ligand and $\mathrm{ZnO}$ c) $0.5: 1$, d) $1: 1$, e) 3:1, f) 5:1 and the different etching time g) $3 \mathrm{~h}, \mathrm{~h}) 6 \mathrm{~h}$, i) $12 \mathrm{~h}, \mathrm{j}) 18 \mathrm{~h}$. It is worth noting that the etching time is $18 \mathrm{~h}$ when the molar ratio is investigated, and the molar ratio is fixed to $5: 1$ when the etching time is modulated. 


\section{Hydrophobic angle measurement}

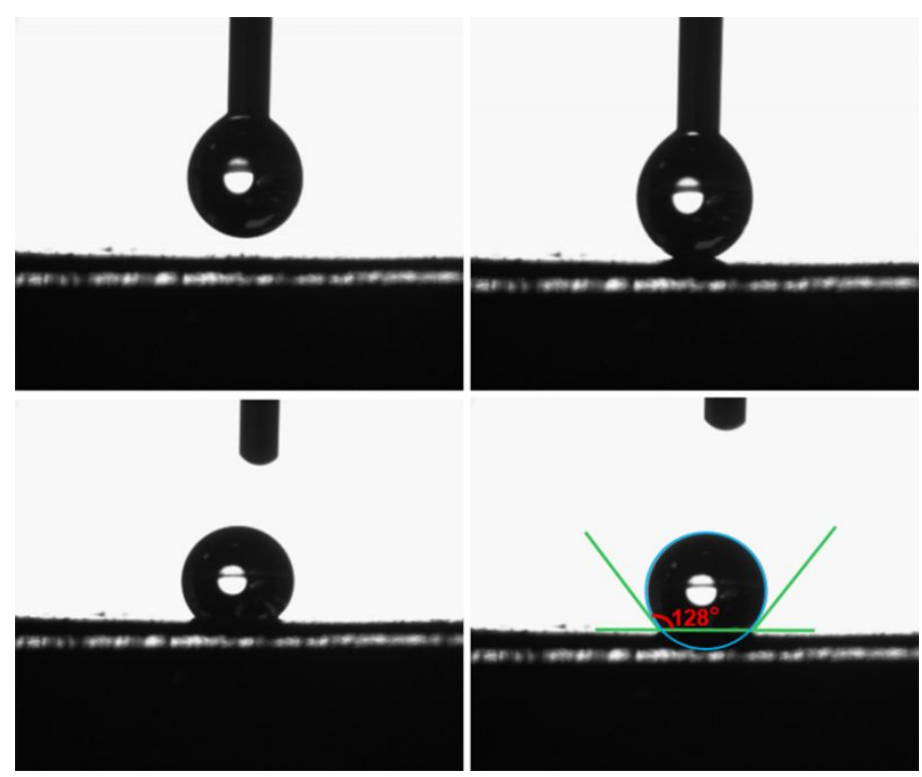

Figure S3. Hydrophobic angle measurement of the Cu-doped ZIF-8 precursor (5:1, $18 \mathrm{~h})$.

XRD patterns and TGA result of the Cu-doped ZIF-8 precursor

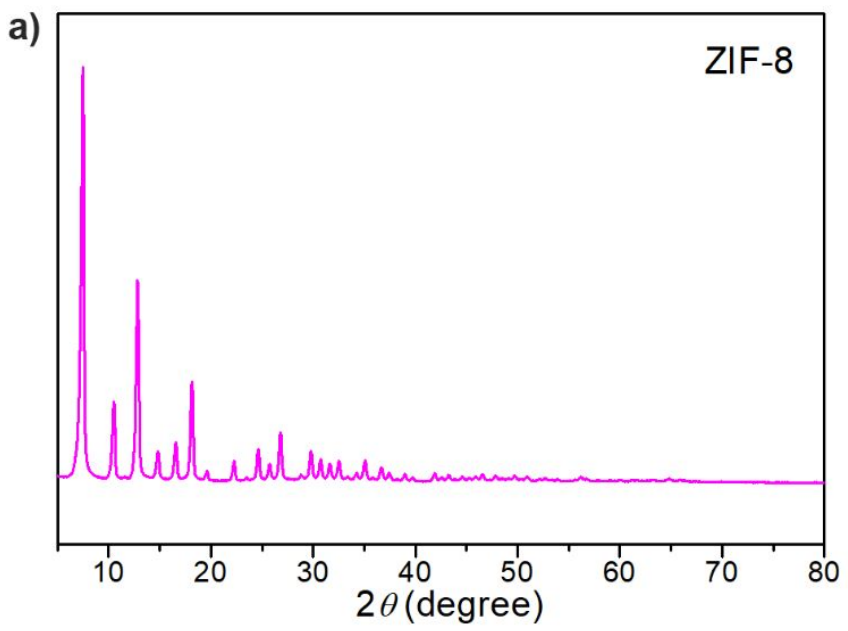




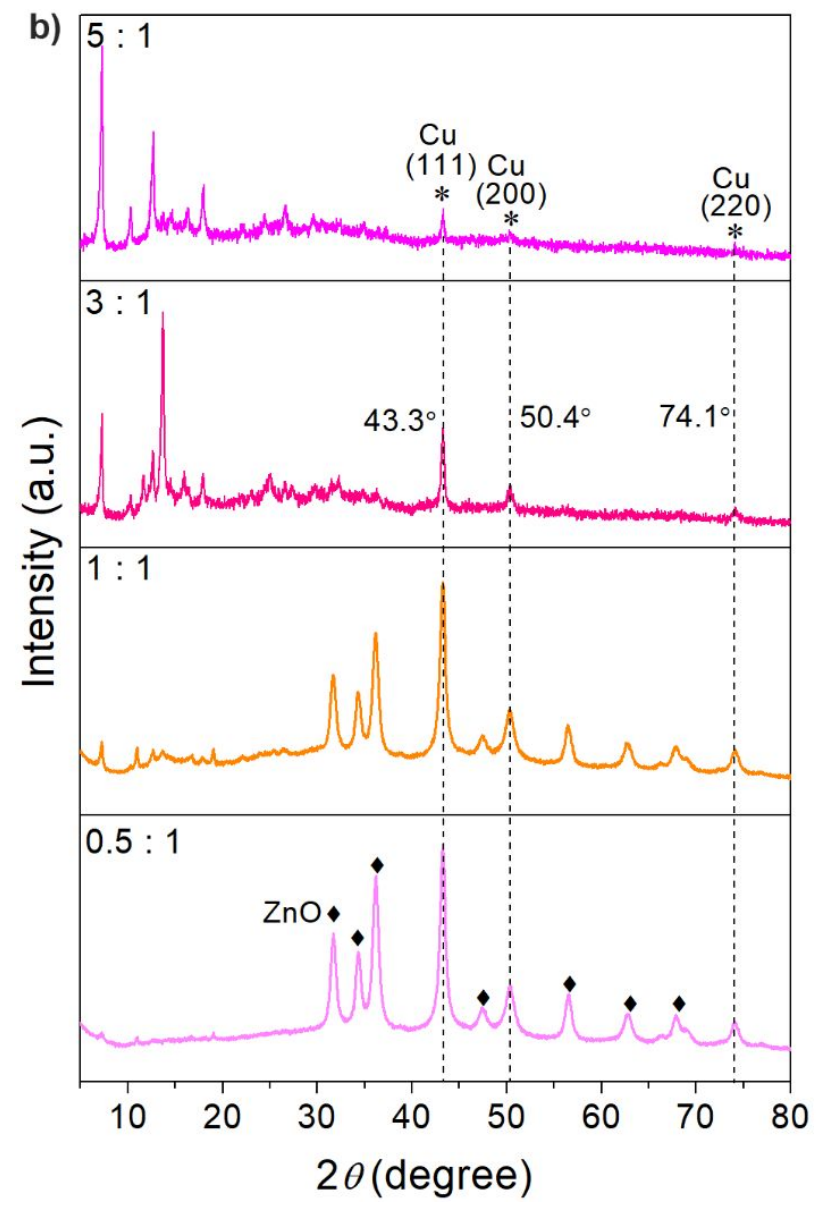

Figure S4. XRD patterns of the a) ZIF-8 and b) Cu-doped ZIF-8 precursor (the etching time is $18 \mathrm{~h}$ ).

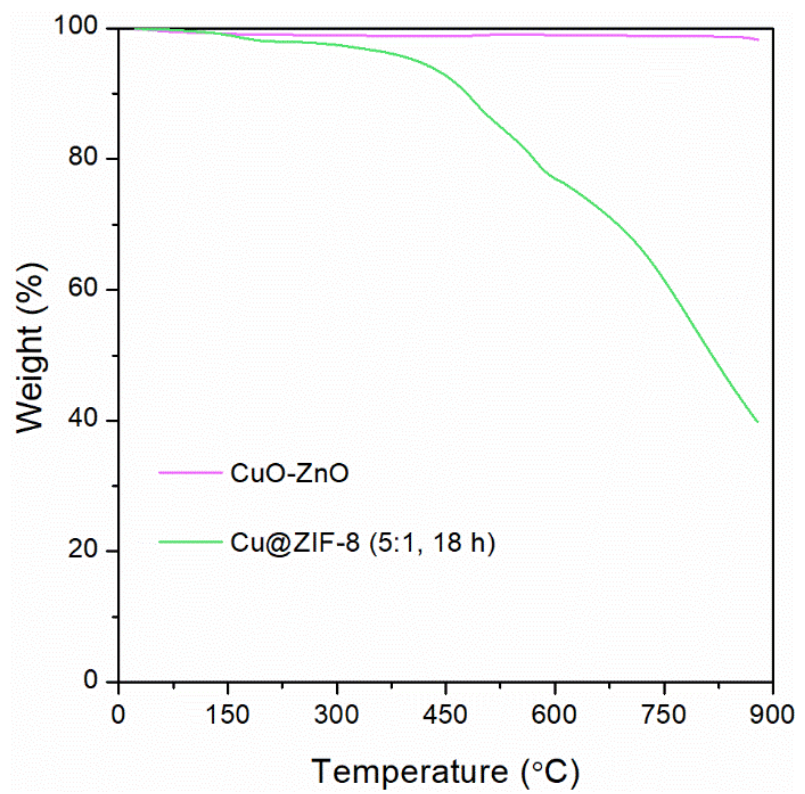

Figure S5. TGA result of the Cu-doped ZIF-8 precursor. 


\section{XRD patterns of the CuZn@C-N samples}

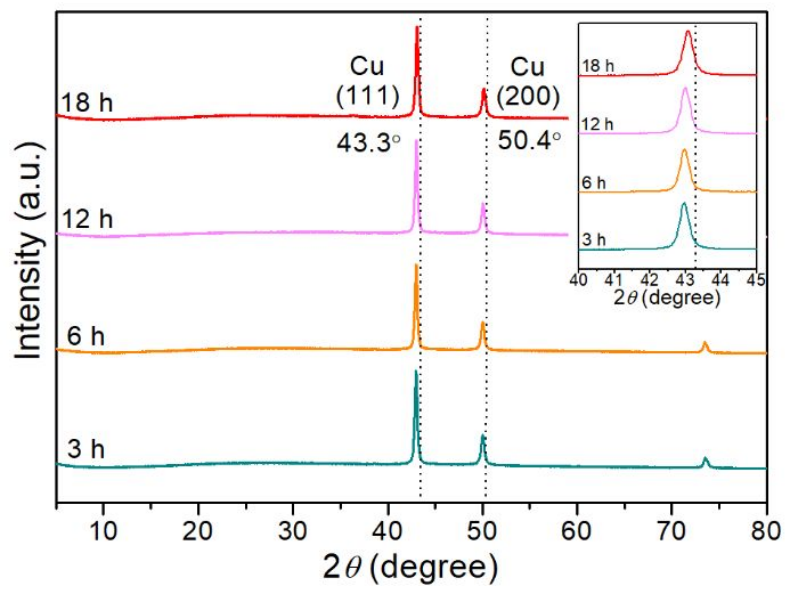

Figure S6. XRD patterns of the CuZn@C-N samples with different etching time (the molar ratio between the ligand and $\mathrm{ZnO}$ is 5:1).

\section{EXAFS and XANES spectra of the CuZn@C-N sample}
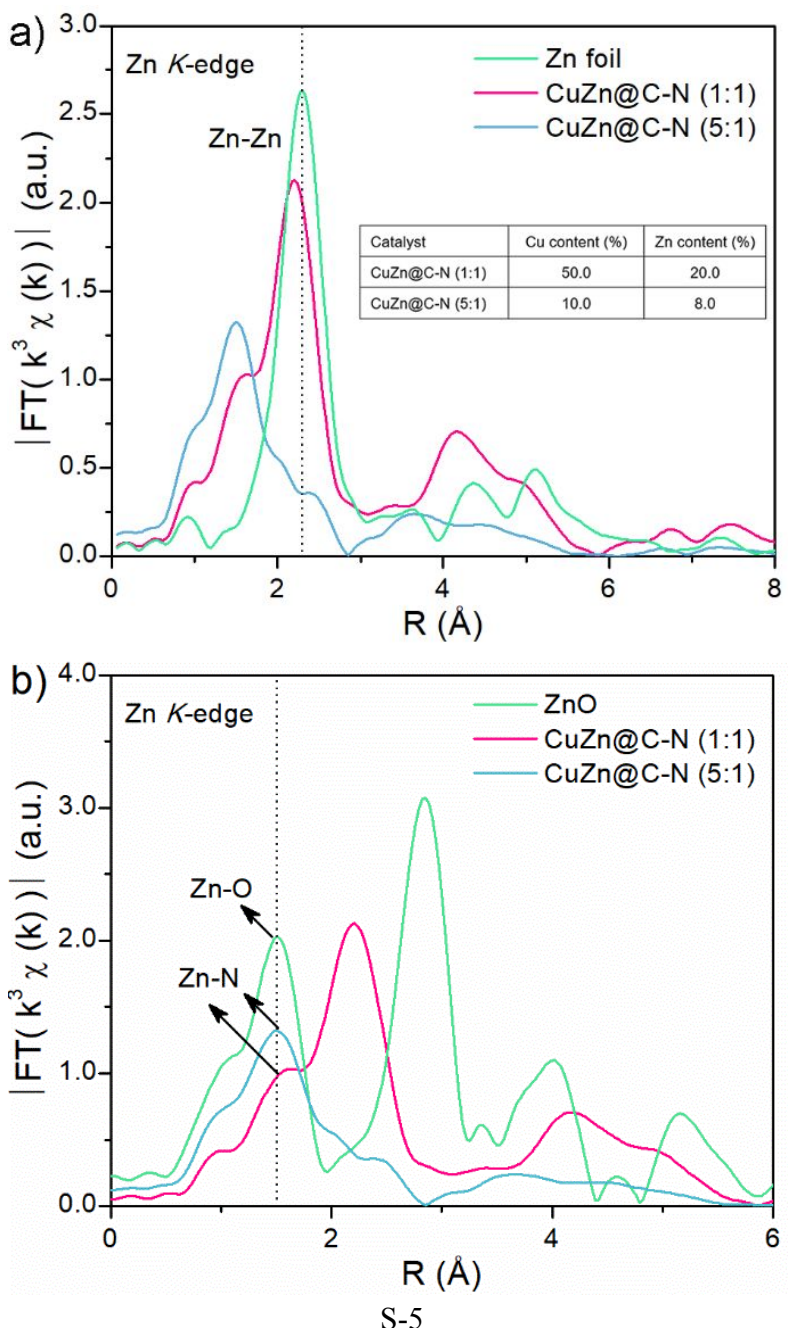


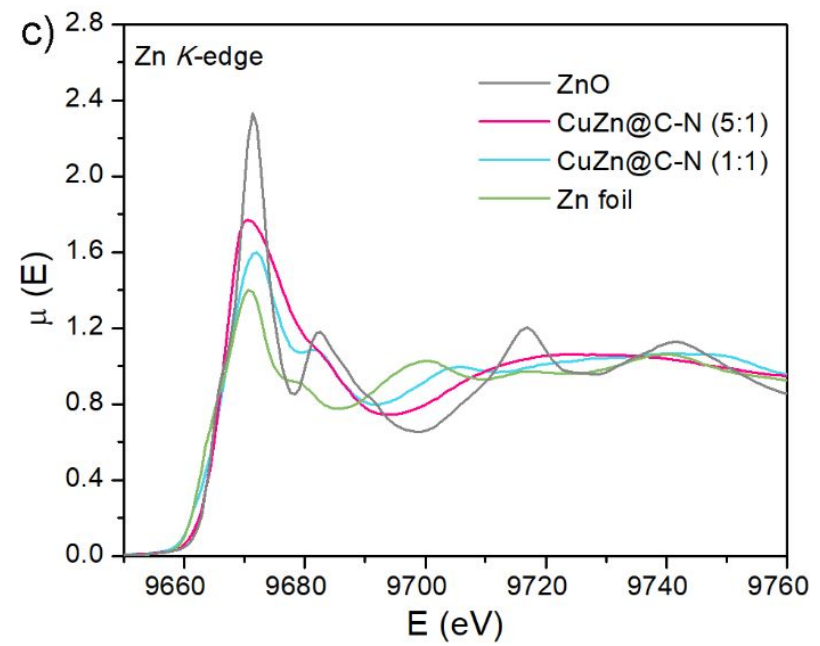

Figure S7. a,b) Fourier transforms of the Zn K-edge EXAFS of the CuZn@C-N sample, Zn foil and ZnO. c) XANES spectra of the $\mathrm{CuZn@C-N} \mathrm{sample,} \mathrm{Zn}$ foil and $\mathrm{ZnO}$. (the etching time of all CuZn@C-N samples is 18 h)

As the metal nodes in ZIF-8, $\mathrm{Zn}$ atoms will combine with $\mathrm{N}$ atoms that coordinate with it to form $\mathrm{ZnN}_{\mathrm{x}}$ species in addition to some $\mathrm{Zn}$ atoms migrating to the $\mathrm{Cu}$ metal core to form alloys. Thus, it is reasonable that the local structure of $\mathrm{Zn}$ atoms in

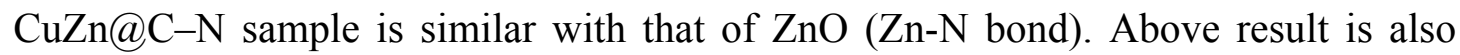
consistent with the reported in the literatures..$^{3,4}$

\section{XPS spectra of Cu@ZIF-8 and CuZn@C-N}

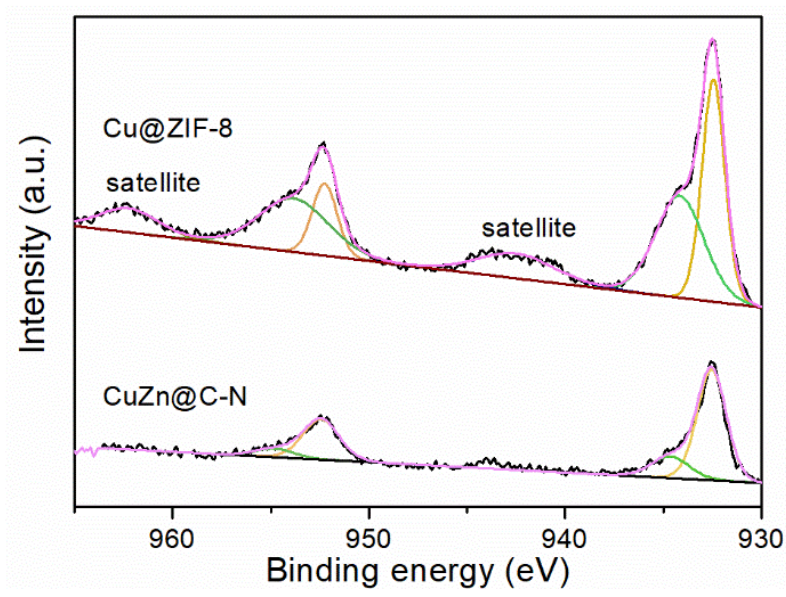

Figure S8. XPS spectra of Cu@ZIF-8 and CuZn@C-N (5:1, 18 h). 


\section{FT-IR spectra of the CuZn@C-N samples}
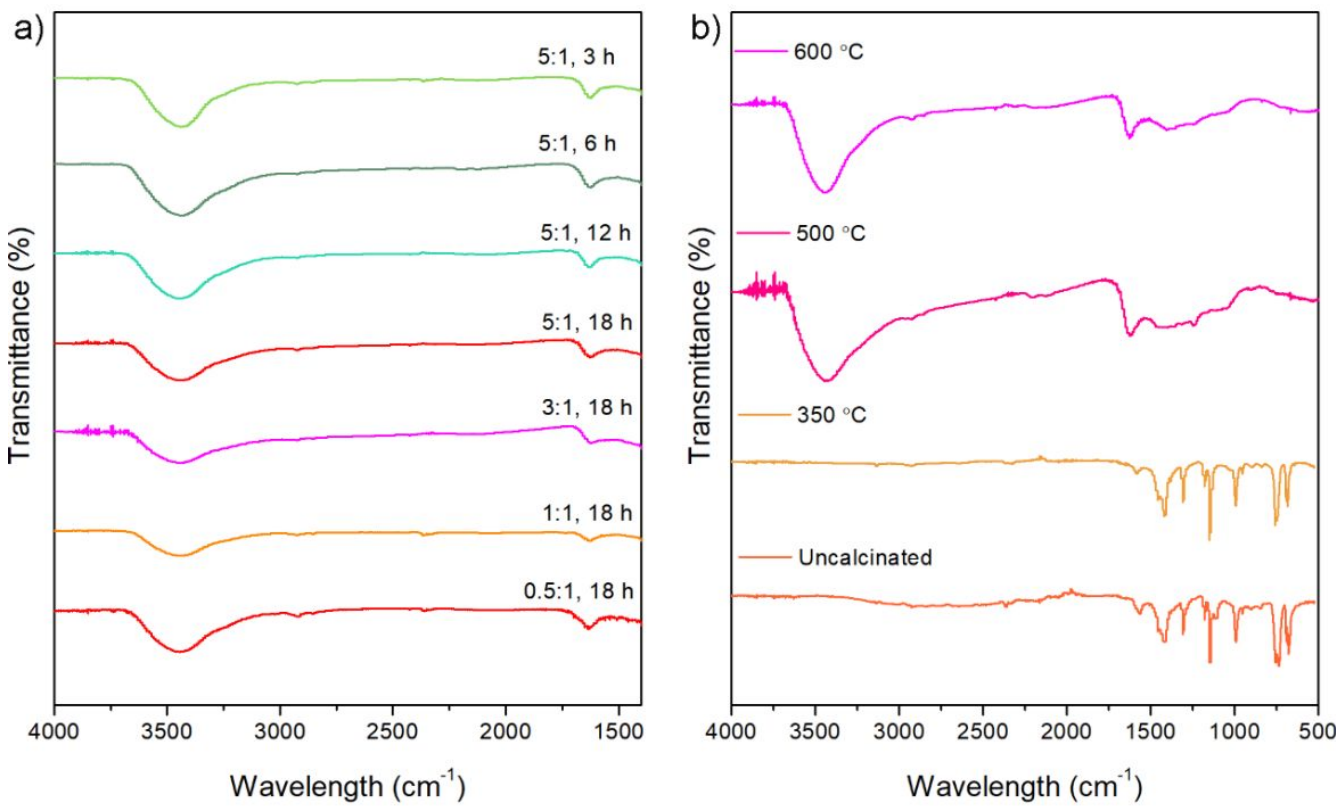

Figure S9. FT-IR spectra of the CuZn@C-N samples including a) the different etching time, the different molar ratio between the ligand and $\mathrm{ZnO}$, and b) the various calcination temperature.

\section{XPS spectra analysis}
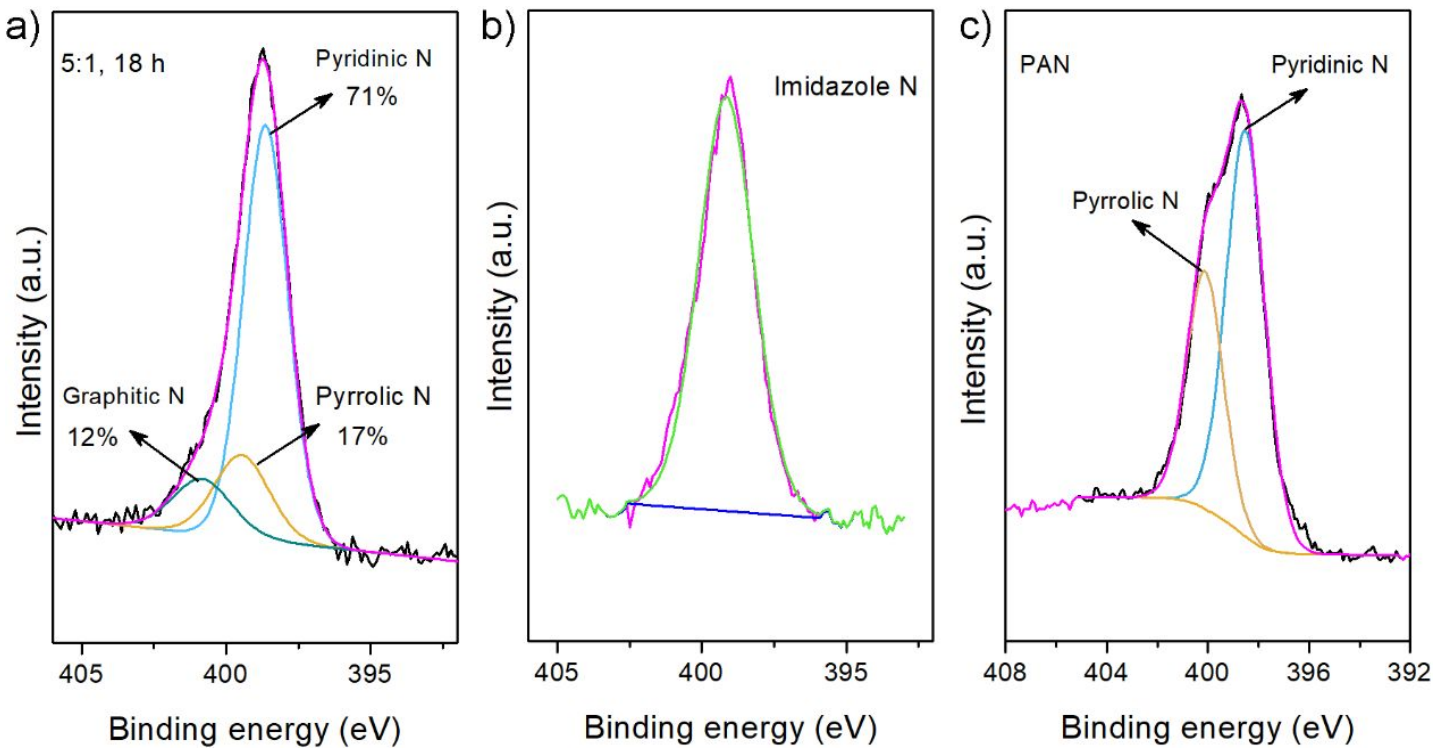

Figure S10. XPS spectra of a) CuZn@C-N (600 $\left.{ }^{\circ} \mathrm{C}\right)$, b) Cu@ZIF-8 and c) PAN (calcination) in $\mathrm{N}$ 1s region. 

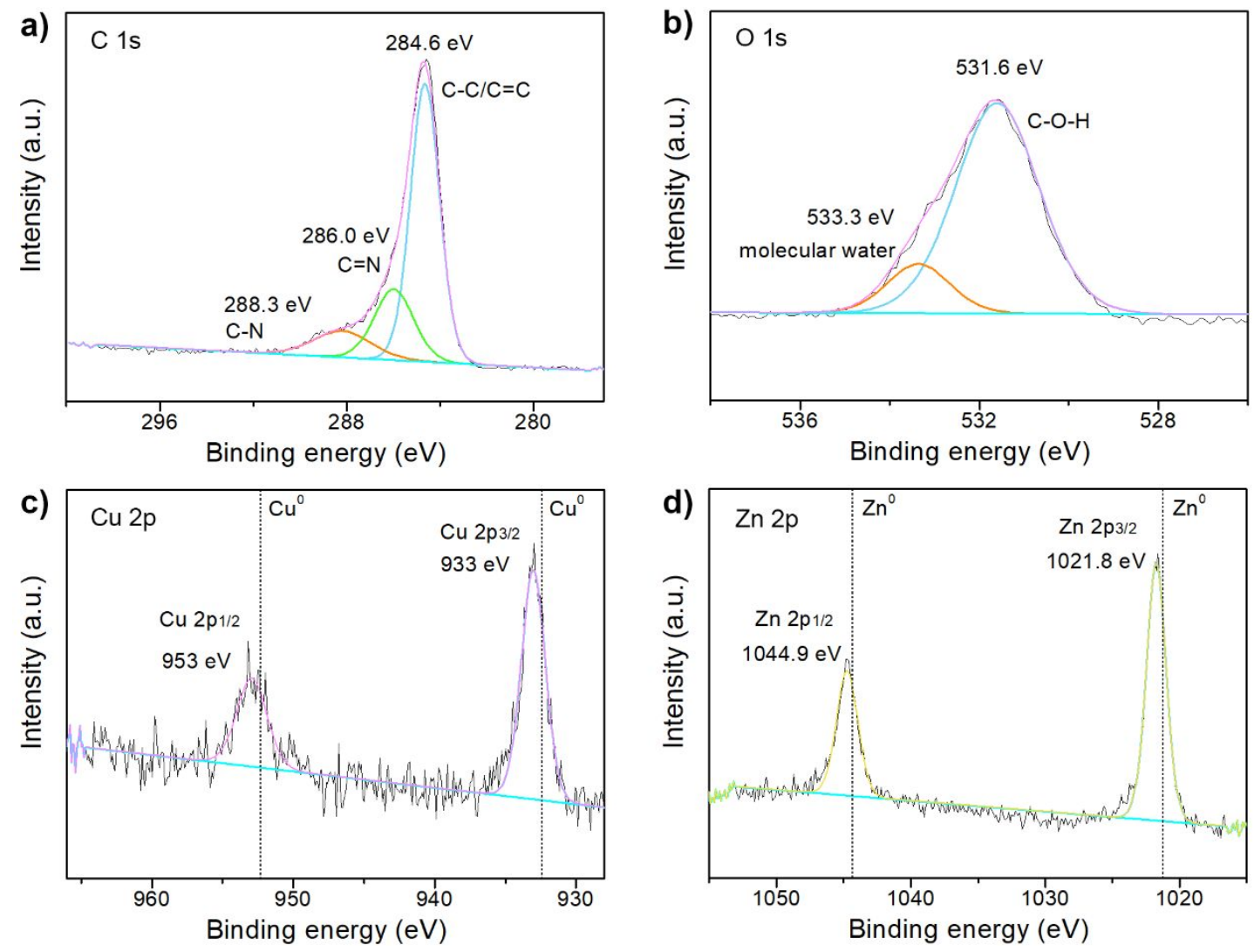

Figure S11. High-resolution XPS spectra of CuZn@C-N (1:1, 18 h): a) C 1s, b) O 1s, c) $\mathrm{Cu} 2 \mathrm{p}$, d) $\mathrm{Zn} 2 \mathrm{p}$.

\section{Element content analysis in shell of $\mathrm{CuZn@C-N}$}

Table S1. Element content analysis in shell of CuZn@C-N.

\begin{tabular}{lll}
\hline Catalyst & N content (\%) & C content $(\%)$ \\
\hline $5: 1,600{ }^{\circ} \mathrm{C}$ & 28.8 & 71.2 \\
$5: 1,500{ }^{\circ} \mathrm{C}$ & 20.4 & 79.6 \\
$1: 1,500^{\circ} \mathrm{C}$ & 18.8 & 81.2 \\
\hline
\end{tabular}




\section{Physical properties of different samples}

Table S2. Physical properties of Cu@ZIF-8 samples.

\begin{tabular}{llll}
\hline Catalysts & $\mathrm{S}_{\mathrm{BET}}\left(\mathrm{m}^{2} / \mathrm{g}\right)$ & Pore size $(\mathrm{nm})$ & Pore volume $\left(\mathrm{cm}^{3} / \mathrm{g}\right)$ \\
\hline $5: 1,18 \mathrm{~h}$ & 588.2 & 1.26 & 0.02 \\
$3: 1,18 \mathrm{~h}$ & 176.4 & 1.26 & 0.01 \\
$1: 1,18 \mathrm{~h}$ & 102.2 & 1.26 & 0.02 \\
$0.5: 1,18 \mathrm{~h}$ & 83.8 & 1.26 & 0.10
\end{tabular}

Table S3. Physical properties of CuZn@C-N samples with different content of ligand.

\begin{tabular}{llll}
\hline Catalysts & $\mathrm{S}_{\mathrm{BET}}\left(\mathrm{m}^{2} / \mathrm{g}\right)$ & Pore size $(\mathrm{nm})$ & Pore volume $\left(\mathrm{cm}^{3} / \mathrm{g}\right)$ \\
\hline $5: 1,18 \mathrm{~h}$ & 2.3 & 2.8 & 0.01 \\
$3: 1,18 \mathrm{~h}$ & 2.2 & 2.2 & 0.01 \\
$1: 1,18 \mathrm{~h}$ & 6.8 & 10.9 & 0.02 \\
$0.5: 1,18 \mathrm{~h}$ & 27.1 & 4.8 & 0.08 \\
\hline
\end{tabular}

Table S4. Physical properties of CuZn@C-N samples with different etching time.

\begin{tabular}{llll}
\hline Catalysts & $\mathrm{S}_{\text {BET }}\left(\mathrm{m}^{2} / \mathrm{g}\right)$ & Pore size $(\mathrm{nm})$ & Pore volume $\left(\mathrm{cm}^{3} / \mathrm{g}\right)$ \\
\hline $5: 1,18 \mathrm{~h}$ & 2.3 & 2.8 & 0.01 \\
$5: 1,12 \mathrm{~h}$ & 1.4 & 2.2 & 0.01 \\
$5: 1,6 \mathrm{~h}$ & 30.1 & 8.2 & 0.14 \\
$5: 1,3 \mathrm{~h}$ & 45.1 & 2.0 & 0.15 \\
\hline
\end{tabular}

Table S5. Physical properties of untreated and calcined PAN samples.

\begin{tabular}{llll}
\hline Catalysts & $\mathrm{S}_{\mathrm{BET}}\left(\mathrm{m}^{2} / \mathrm{g}\right)$ & Pore size $(\mathrm{nm})$ & Pore volume $\left(\mathrm{cm}^{3} / \mathrm{g}\right)$ \\
\hline PAN & 5.2 & 3.8 & 0.03 \\
PAN-calcination & 103.7 & 28.3 & 0.50 \\
\hline
\end{tabular}


Table S6. Physical properties of CuZn alloy samples prepared by different method.

\begin{tabular}{lll}
\hline Catalysts & $\mathrm{S}_{\mathrm{BET}}\left(\mathrm{m}^{2} / \mathrm{g}\right)$ & Pore volume $\left(\mathrm{cm}^{3} / \mathrm{g}\right)$ \\
\hline Co-precipitation & 64 & 0.12 \\
Calcination nitrates & 19 & 0.05 \\
\hline
\end{tabular}

\section{$\mathrm{CO}_{2}$-TPD analysis}
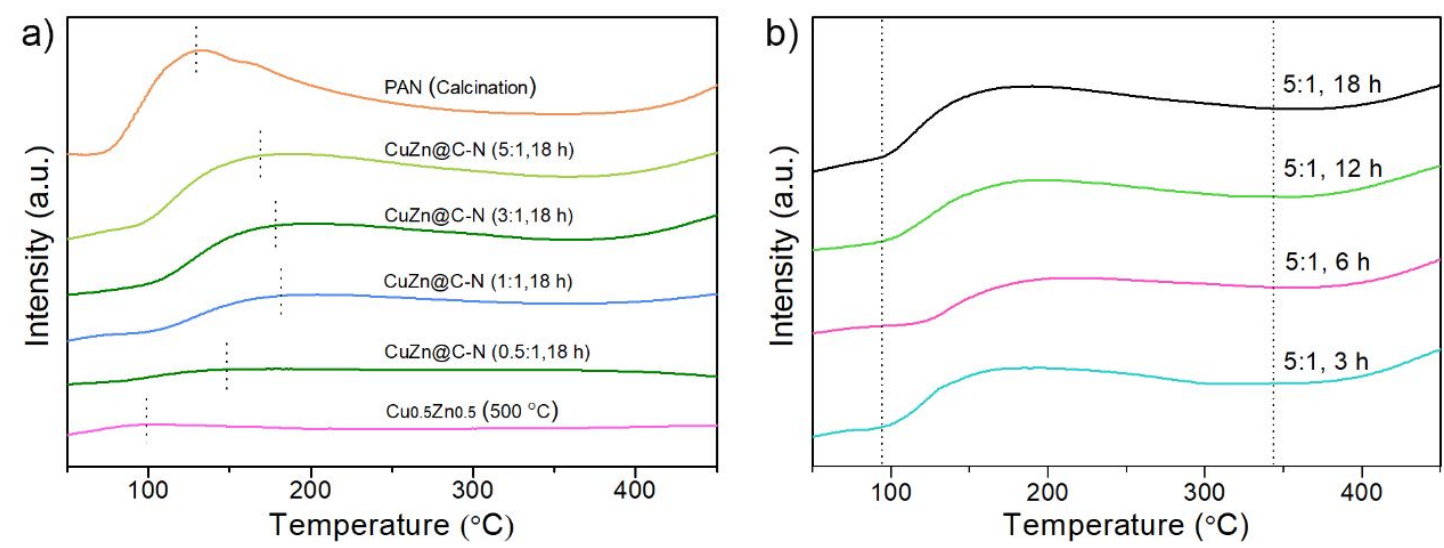

Figure S12. $\mathrm{CO}_{2}$-TPD of the as-calcined PAN, CuZn alloy and the $\mathrm{CuZn} @ \mathrm{C}-\mathrm{N}$ samples.

\section{Element content analysis of metal in $\mathrm{CuZn@C-N} \mathrm{samples}$}

Table S7. Element content analysis of metal in $\mathrm{CuZn} @ \mathrm{C}-\mathrm{N}$ samples.

\begin{tabular}{lll}
\hline Catalyst & Cu content (\%) & Zn content (\%) \\
\hline CuZn@C-N (0.5:1) & 71 & 29 \\
CuZn@C-N (1:1) & 68 & 32 \\
CuZn@C-N (3:1) & 59 & 41 \\
CuZn@C-N (5:1) & 55 & 45 \\
\hline
\end{tabular}




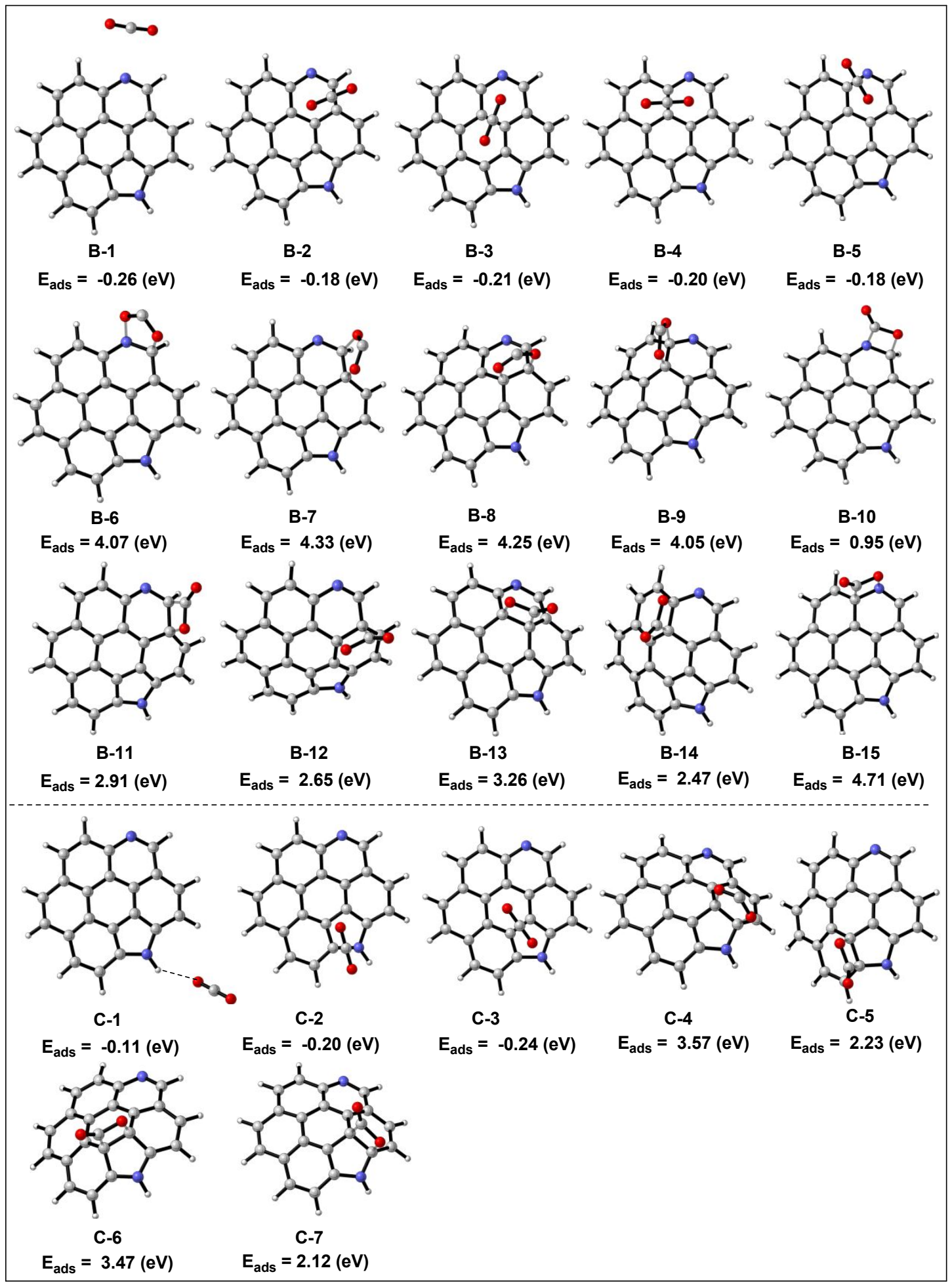

Figure S13. Optimized geometries of the carbon dioxide adsorbed onto pyridine (B) and pyrrole (C), respectively. 


\section{Calculation details:}

Geometry optimizations and single-point solvation energy calculations were performed with the M06-2X ${ }^{[1]}$ functional implemented in Gaussian 09 ${ }^{[2]}$. For all atoms, the 6$311+\mathrm{G}(\mathrm{d}, \mathrm{p})$ basis set was employed in geometry optimizations and single-point energy calculations. Frequency analyses were carried out to confirm that each structure is a local minimum (no imaginary frequency).

\section{XRD patterns of the $\mathrm{CuO}-\mathrm{ZnO}$ precursor with different treatment}

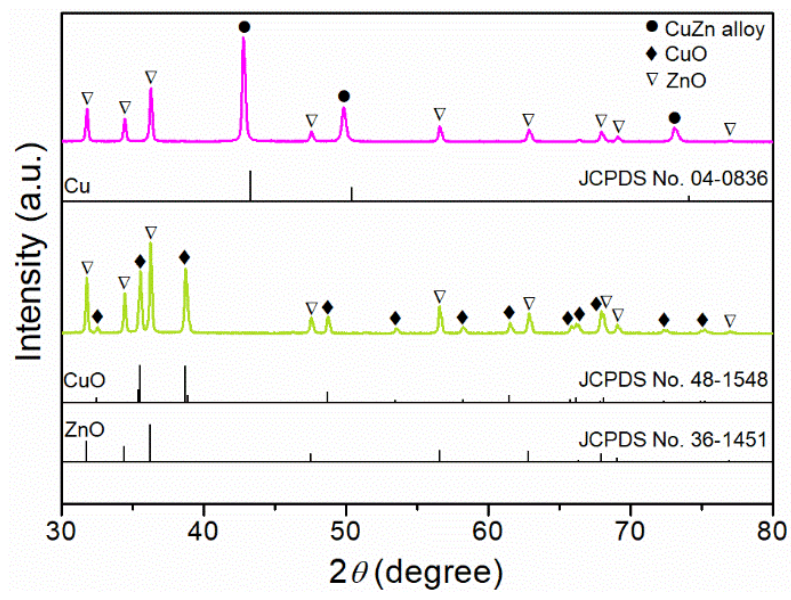

Figure S14. XRD patterns of the $\mathrm{CuO}-\mathrm{ZnO}$ precursor with different treatment: green) calcined at $500{ }^{\circ} \mathrm{C}$; red) calcined at $500{ }^{\circ} \mathrm{C}$ and then reduced at $500{ }^{\circ} \mathrm{C}$.

\section{Comparison of the RWGS catalytic performances}

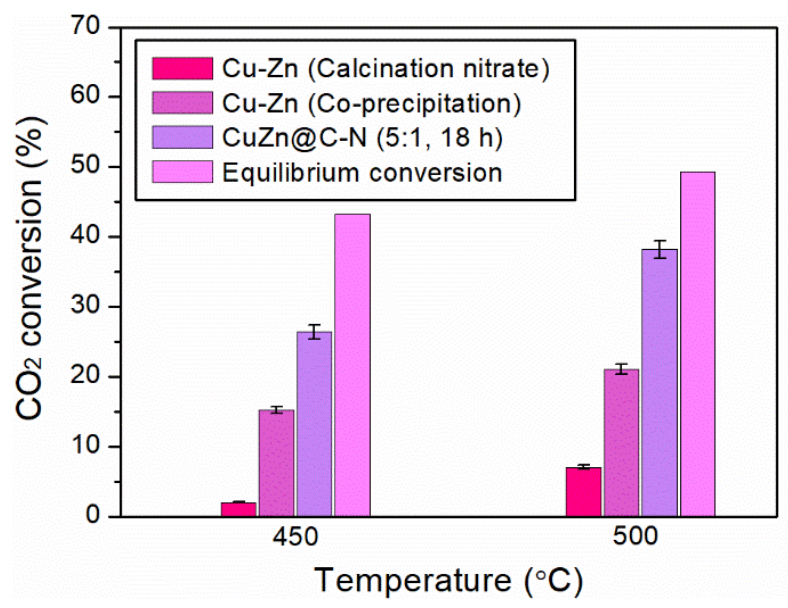

Figure S15. Comparison of the RWGS catalytic performances between CuZn alloy that prepared by co-precipitation and calcination nitrates and the as-prepared $\mathrm{CuZn} @ \mathrm{C}-\mathrm{N}$. 
Table S8. Summary of the catalytic performance of different catalysts.

\begin{tabular}{lllll}
\hline Catalyst & Reaction condition & $\mathrm{CO}_{2}$ conversion (\%) & CO selectivity (\%) & Reference \\
\hline 4-Pt/Au@Pd@1Co & $400{ }^{\circ} \mathrm{C}, 2.0 \mathrm{MPa}$ & 15.6 & 87.5 & {$[5]$} \\
$\mathrm{Pt} / \mathrm{MOF}-74-24$ & $400{ }^{\circ} \mathrm{C}, 2.0 \mathrm{MPa}$ & 34 & $>99$ & {$[6]$} \\
$\mathrm{Au} @ \mathrm{UIO}-67-\mathrm{H}_{2}$ & $408^{\circ} \mathrm{C}, 2.0 \mathrm{MPa}$ & 30 & $>96.5$ & {$[7]$} \\
$\mathrm{CuSiO} / \mathrm{CuO}_{\mathrm{x}}$ & $500^{\circ} \mathrm{C}, 0.1 \mathrm{MPa}$ & 17.8 & $>99$ & {$[8]$} \\
$\mathrm{Cu} / \mathrm{\beta}-\mathrm{Mo}{ }_{2} \mathrm{C}$ & $500{ }^{\circ} \mathrm{C}, 0.1 \mathrm{MPa}$ & 30 & $>99$ & {$[9]$} \\
$\mathrm{CuZn} @ \mathrm{C}-\mathrm{N}$ & $500{ }^{\circ} \mathrm{C}, 0.1 \mathrm{MPa}$ & 39 & $>99$ & This work \\
\hline
\end{tabular}

\section{References}

(1) Zhao, Y.; Truhlar, D. G. The M06 Suite of Density Functionals for Main Group Thermochemistry, Thermochemical Kinetics, Noncovalent Interactions, Excited States, and Transition Elements: Two New Functionals and Systematic Testing of Four M06Class Functionals and 12 Other Functionals. Theor. Chem. Acc. 2008, 120, 215.

(2) Frisch, M. J.; Trucks, G. W.; Schlegel, H. B.; Scuseria, G. E.; Robb, M. A.; Cheeseman, J. R.; Scalmani, G.; Barone, V.; Mennucci, B.; Petersson, G. A.; Nakatsuji, H.; Caricato, M.; Li, X.; Hratchian, H. P.; Izmaylov, A. F.; Bloino, J.; Zheng, G.; Sonnenberg, J. L.; Hada, M.; Ehara, M.; Toyota, K.; Fukuda, R.; Hasegawa, J.; Ishida, M.; Nakajima, T.; Honda, Y.; Kitao, O.; Nakai, H.; Vreven, T.; Jr. Montgomery, J. A.; Peralta, J. E.; Ogliaro, F.; Bearpark, M.; Heyd, J. J.; Brothers, E.; Kudin, K. N.; Staroverov, V. N.; Kobayashi, R.; Normand, J.; Raghavachari, K.; Rendell, A.; Burant, J. C.; Iyengar, S. S.; Tomasi, J.; Cossi, M.; Rega, N.; Millam, J. M.; Klene, M.; Knox, J. E.; Cross, J. B.; Bakken, V.; Adamo, C.; Jaramillo, J.; Gomperts, R.; Stratmann, R. E.; Yazyev, O.; Austin, A. J.; Cammi, R.; Pomelli, C.; Ochterski, J. W.; Martin, R. L.; Morokuma, K.; Zakrzewski, V. G.; Voth, G. A.; Salvador, P.; Dannenberg, J. J.; Dapprich, S.; Daniels, A. D.; Farkas, Ö.; Foresman, J. B.; Ortiz, J. V.; Cioslowski, J.; 
Fox, D. J. Gaussian 09, revision E.01; Gaussian, Inc.: Wallingford, CT, 2013.

(3) Cheng, J.; Liu, N.; Hu, L.; Li, Y.; Wang, Y.; Zhou, J. Polyethyleneimine entwine thermally-treated $\mathrm{Zn} / \mathrm{Co}$ zeolitic imidazolate frameworks to enhance $\mathrm{CO}_{2}$ adsorption. Chem. Eng. J. 2019, 364, 530-540.

(4) Chen, H.; Shen, K.; Mao, Q.; Chen, J.; Li, Y. Nanoreactor of MOF-Derived Yolk-Shell Co@C-N: Precisely Controllable Structure and Enhanced Catalytic Activity. ACS Catal. 2018, 8, 1417-1426.

(5) Zhao, X.; Xu, H.; Wang, X.; Zheng, Z.; Xu, Z.; Ge, J. Monodisperse Metal-Organic Framework Nanospheres with Encapsulated Core-Shell Nanoparticles Pt/Au@Pd@ $\left\{\mathrm{Co}_{2}(\mathrm{oba})_{4}(3-\mathrm{bpdh})_{2}\right\} 4 \mathrm{H}_{2} \mathrm{O}$ for the Highly Selective Conversion of $\mathrm{CO}_{2}$ to CO. ACS Appl. Mater. Interfaces 2018, 10, 15096-15103.

(6) Han Y.; Xu H.; Su, Y.; Xu, Z.; Wang, K.; Wang, W.; Noble Metal (Pt, Au@Pd) Nanoparticles Supported on Metal Organic Framework (MOF-74) Nanoshuttles as High-Selectivity $\mathrm{CO}_{2}$ Conversion Catalysts. J. Catal. 2019, 370, 70-78.

(7) Xu, H.; Li, Y.; Luo, X.; Xu, Z.; Ge, J. Monodispersed Gold Nanoparticles Supported on a Zirconium-Based Porous Metal-Organic Framework and Their High Catalytic Ability for the Reverse Water-Gas Shift Reaction. Chem. Commun. 2017, 53, $7953-7956$.

(8) Yu, Y.; Jin, R.; Easa, J.; Lu, W.; Yang, M.; Liu, X.; Xing, Y.; Shi, Z. Highly Active and Stable Copper Catalysts Derivedfrom Copper Silicate Double-Shell Nanofibers with Strong Metal-Support Interactions for the RWGS Reaction. Chem. Commun. 2019, $55,4178-4181$.

(9) Zhang, X.; Zhu, X.; Lin, L.; Yao, S.; Zhang, M.; Liu, X.; Wang, X.; Li, Y. W.; Shi, C.; Ma, D. Highly Dispersed Copper over $\beta-\mathrm{Mo}_{2} \mathrm{C}$ as an Efficient and Stable Catalyst for the Reverse Water Gas Shift (RWGS) Reaction. ACS Catal. 2017, 7, 912-918. 